\title{
FIGYELEMFELKELTŐ BEMUTATÓ ESZKÖZ TOVÁBBFEJLESZTÉSÉNEK LEHETŐSÉGEI
}

\author{
Bubonyi Andrea \\ MSc géptervezö hallgató, Miskolci Egyetem \\ Gép-és Terméktervezési Intézet \\ 3515 Miskolc, Miskolc-Egyetemváros, e-mail: buboandi@gmail.com \\ Bihari Zoltán \\ egyetemi docens, Miskolci Egyetem \\ Gép- és Terméktervezési Intézet \\ 3515 Miskolc, Miskolc-Egyetemváros, e-mail: machbz@uni-miskolc.hu
}

\begin{abstract}
Absztrakt:
Ennek a cikknek az alapja egy ipari feladat, amely egy szokatlan termékbemutató paletta megtervezését tüzte ki célul. A munka eredménye egy humanoid alakú robot, amely képes bizonyos mozdulatok elvégzésére is.
\end{abstract}

Kulcsszavak: humanoid robot, alumínium profil, profil összekötö

\section{Abstract:}

This article is based on an industry task that aims to design an unusual product demonstration palette. The result of this work is a humanoid-shaped robot that can perform certain movements.

Keywords: humanoid robot, aluminium profil, profil connector

\section{Bevezetés, cégismertető röviden}

A FATH Components Kft. egy német anyavállalattal rendelkező cég, amely föleg profil összekötő elemeket gyárt, illetve értékesít. A vállalat 1989-ben alapult Spalt-ban, Németország területén.

A cégnek fontos, hogy a fiatal mérnökök megismerkedjenek a profilelemek sokszínü felhasználhatóságával, ezért több iskolával, többek között a Miskolci Egyetemmel is partnerkapcsolatot ápol már sok éve. Az együttmüködés keretében évente több alkalommal tartanak az egyetemeken érdekes prezentációkat, valamint jellegzetes alkatrészeket mutatnak be a tanórák keretein belül, cégismertetőt tartanak, illetve szerelési gyakorlatot végeznek a hallgatókkal. Több esetben előfordult, hogy termékeikkel támogatták egy-egy szakdolgozat megvalósulását is. A BSc szakdolgozatom írása közben felmerült annak a lehetősége, hogy megvalósítsunk egy helyszíni akusztikai mérések elvégzésére tervezett mérőkocsit. Ehhez szükség volt a FATH Components Kft. támogatására, amely során számos összekötő elemmel szponzorálták a munkát. 


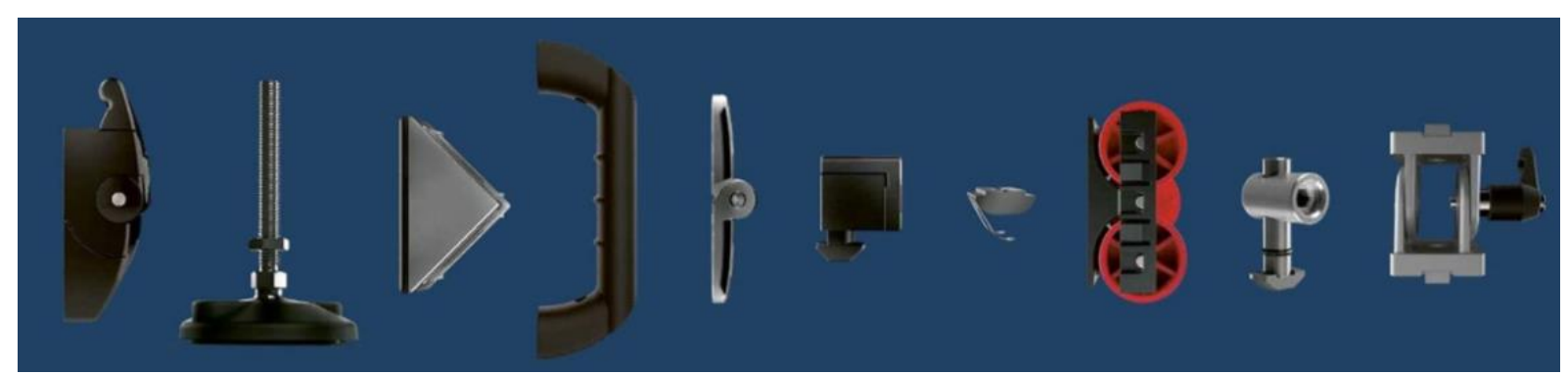

1. ábra. A FATH Components Kft. termékei [1]

A céggel nagyon könnyü volt együtt dolgozni, mindig elérhetőek és segítőkészek voltak, így igen jó benyomást keltettek. A későbbiek során hallgatók nyári szakmai gyakorlataival, valamint gyakornoki szerződéssel egészült ki az együttmüködés. 2019 nyarától jómagam már fơállásban dolgozom a budaörsi telephelyükön.

\section{A feladat megszületése}

A termékbemutató platform tervezése januárban induló projekt volt. A cél az volt, hogy a már meglévő termékbemutató eszközeinken túl valami nagyobbat és figyelemfelkeltőbbet alkossunk, ami akár egy kiállításon is megállja a helyét.

Korábban is volt már a cég életében egy-két bemutató eszköz, de egyik sem volt akkora volumenü, hogy tömegeket vonzzon oda a kiállító standhoz. Ezeknek a bemutató eszközöknek köszönhetően azonban már volt némi fogalmunk arról, hogy mire kíváncsi egy-egy mérnök vagy értékesítő partner a termékeinkkel kapcsolatban. Így tehát viszonylag könnyen fel tudtuk állítani az igényjegyzéket. Alapvető jelentőségü volt például, hogy minél több különböző alkatrészt megmutassunk, és fontosnak éreztük, hogy beszerelt állapotban is, és kézbe foghatóan is szeretnek az ügyfeleink találkozni ezekkel. Ide sorolható még olyan elgondolás is, hogy ne csak a hagyományos módokon szereljük be az elemeket, hiszen azt a legtöbben könnyen el tudják képzelni, hanem legyünk kreatívak, mert az új ötletekre is vevők az érdeklődők.

Az első lépések egyike volt, hogy kigondoljuk, hogy mi legyen az alapja a bemutató eszköznek. Ez egy hosszas brainstorming (ötletelés) során született meg. A folyamatban részt vettek az értékesítő kollégák, a cégvezető, a termékmenedzser és jómagam is. Végül több lehetséges megoldás is született.

$\mathrm{Az}$ egyik, egy mindenki által preferált, humanoid alak volt. Külső méretei egy egészséges férfi méreteivel egyezzenek meg, azonban a felépítése kizárólag alumínium profilból lehet, és minden összekötés a mi elemeinkkel kell, hogy történjen.

A másik megszavazott projekt egy kiállító kocsi volt, ami jóval több energia- és anyagi befektetést igényelt, így az emberalakot jelöltük meg prioritásként.

\section{A humanoid alak megvalósítása}

A tervezés a FATH Components Kft.-nél használt SolidWorks 3D-s tervező programmal folyt. A betervezett alkatrészek mennyisége miatt úgy döntöttünk, hogy a profil geometriát csak egyszerüsítve rajzoljuk meg, a horonymélységet, a magméretet és a befoglaló méretet megjelenítve. 

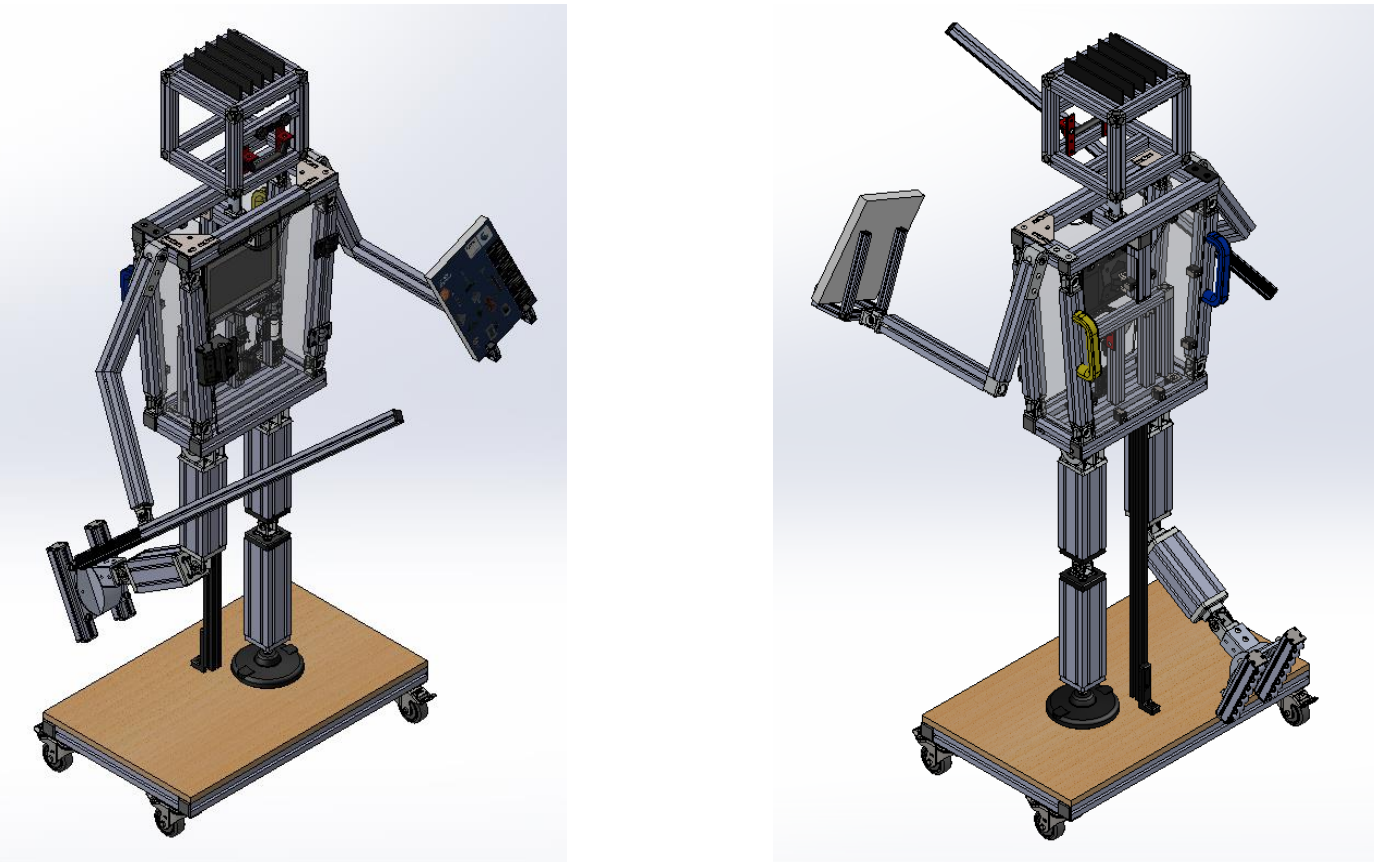

2. ábra. A kész humanoid alak SolidWorks-ben

Az emberalak nagyon előnyös választás volt számunkra olyan tekintetben, hogy nemcsak az összekötő elemeink sokféleségét tudjuk felvonultatni, hanem a különböző méretü profilok egymáshoz kötési lehetőségeit is. Ez nagy előnye a FATH Components Kft. termékeinek, a többi hasonló céggel szemben.

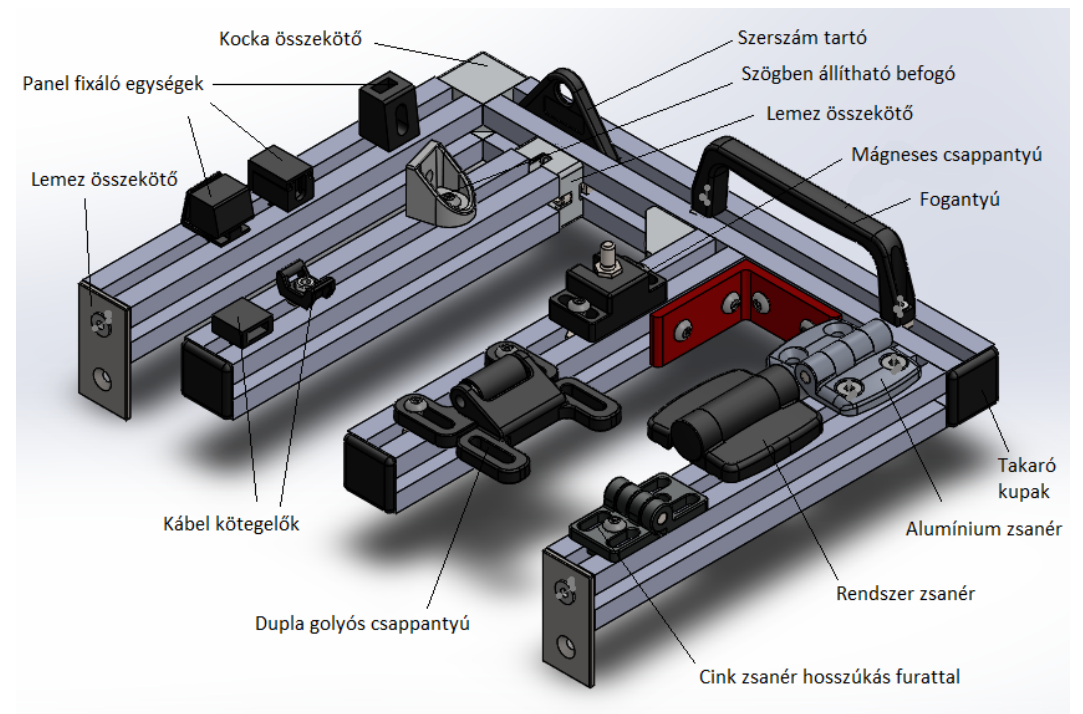

3. ábra. A ,belek” 
A munkát módszeresen végezve, az emberalakot több részegységre bontottuk fel. A feje volt az első, amin hajat imitáló kefesor, szájként müködő fogantyú és szemnek kinéző gépláb is helyet kapott. A nyaka felvonultatja a csőprofil-rendszerekhez használatos elemeinket, és tetszőleges szögben állítható.

A teste minden kapcsolódási pontja más és más összekötőkkel épült fel, valamint helyet kapott a mellkasában egy monitortartó is, egy tablettel kiegészítve. A táblagépen promóciós videót tervezünk vetíteni. Itt kaptak még helyet a 3. ábrán látható ún. „belek” is.

Ez a rész az alján lévő lemez összekötők, és a „Robi”-nak elnevezett emberalak belsejében lévő mágneses csappantyúnak köszönhetően kivehető a testből. Mindenféle alkatrész megtalálható rajta, legtöbbjük levehetö, mozgatható, forgatható, megcsodálható testközelböl.

Érdemes még megemlíteni az elöl lévő zárat, amelyet általában robotcellák müködéséhez szoktak használni. Képes érzékelni, hogy nyitva vagy zárva van-e az ajtó, és ezáltal a hozzákötött led fénysorban megkülönböztetett fényjelzést adni. Ezek a ledek a robot fejébe kerültek, így az arca világít zölden, illetve pirosan az ajtó állapotától függően. Mivel az így elkészült szerkezet mindenképp áramforrást igényel, úgy döntöttünk, hogy az egyik kezében lévő kardba is vezetünk egy ledekből álló fénysort, hogy kvázi fénykardként felkeltse az érdeklődést.

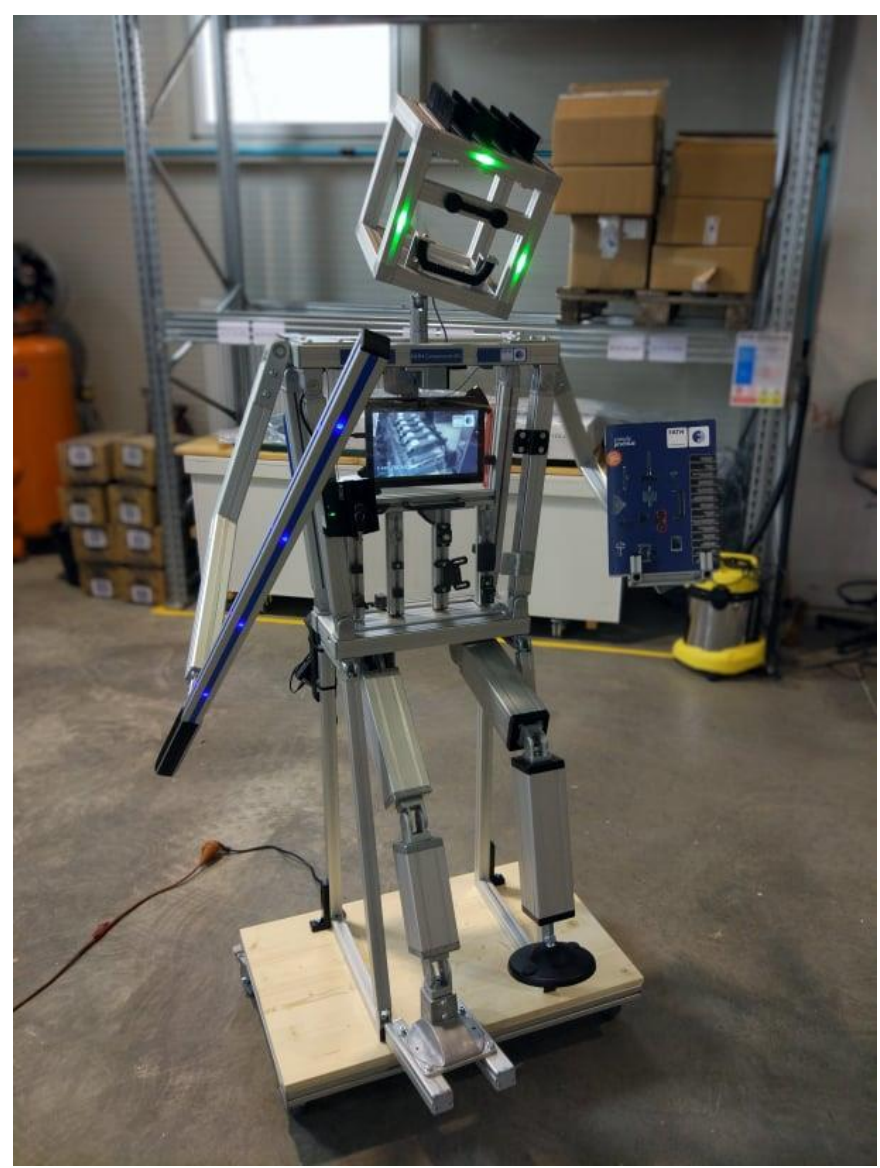

4. ábra. ,Robi” 
Utolsó lépés volt a lábak és az alap megtervezése, illetve egy támasz megtervezése. Termékpalettánk sokszínüségét jellemzi, hogy a tervezés során nem volt olyan ötlet, amit ne tudtunk volna valamilyen elemmel helyettesíteni, így minden felkerült „Robi”-ra, amit fontosnak tartottunk megmutatni.

A 3D modell elkészülése után következett a megvalósítás. A megépítése nehézkes volt, több időt vett igénybe, mivel átgondoltan kellett dolgozni, és ebben nem rendelkeztünk túl sok tapasztalattal. A 4. ábrán a megépült kész szerkezet látható.

\section{A kész szerkezet fejlesztési lehetőségei}

Miután „Robi” megvalósult, eszünkbe jutott még néhány ötlet, amivel még figyelemfelkeltőbbé és izgalmasabbá tehetjük. Egyébként így is nagy sikert aratott, a kollégák elmondása szerint sok érdeklődőt odavonzott a standunkhoz, és többen is fényképezték, illetve szelfiztek vele.

A szóba jövő fejlesztéseket az alábbi módon lehet csoportosítani:

- meglévő szerkezet javítása,

- mozgások megvalósítása.

Mivel a fél lábát fel kell, hogy emelje a korcsolyának álcázott görgősor miatt, így muszáj masszívabban alátámasztani, tehát az alátámasztó keret eltüntetésére egyelöre nincs lehetőségünk. Azonban mozgatás téren több eshetőség is felvetődött. Az egyik javaslat az volt, hogy a kardot tartó keze végezzen valamilyen alternáló mozgást, azonban a nagy kiterjedése miatt ezt veszélyesnek éreztük egy kiállításon. Így mérlegelni kellett, hogy a kar mozgása miatt kapjon-e egy külön ketrecet, ami védi a látogatókat, ennek a megoldásnak viszont az volt a hátránya, hogy nem tudnak olyan közel menni hozzá az érdeklődők, hogy mindent megnézzenek rajta. Mivel egyelöre az a cél, hogy a közönség lássa, és fizikai kontaktusuk legyen a profilokkal és azok összekötő elemeivel, így elvetettük ezen ötletet.

A másik javaslat a fejének mozgatása volt, függőleges tengely mentén, azaz, hogy el tudja fordítani jobbra és balra, valamilyen program szerint. Ez megvalósítható ötletnek tünt, így hozzákezdtünk a kivitelezéshez.

\section{A fej mozgatásának megvalósítása}

Úgy határoztunk, hogy a tervezés és a megvalósítás folyamatát időben párhuzamosan végezzük. Így a fej prototípusát megépítettük a Miskolci Egyetemen, miközben a mozgatás mechanikai, elektronikai és programozástechnikai kérdéseivel foglalkoztunk. Az elkészült fej váz modelljére felkerült a nyak rész, a vállai helyére azonban egy egyszerü tartószerkezetet terveztünk. Ezzel rendelkezésünkre állt a fejleszteni kívánt terület úgy, hogy közben az igazi robotot nem szedtük szét, hanem a budaörsi irodában tartottuk. A terveink szerint a Miskolci Egyetemen lévő modellen a mozgás jól szimulálható, az esetleges változtatások könnyebben kivitelezhetőek, így a már kipróbált jó megoldást juttatjuk vissza a vállalathoz a valós robotba beépítve. Ezzel a módszerrel szükségtelenné válik a teljes szerkezet utaztatása Budaörs és Miskolc között.

A mozgatás megvalósítása két fő megválaszolandó kérdést vetett fel. Az egyik az, hogy fizikailag milyen egységekkel történjen ez, a másik pedig, hogy legyen-e eseményvezérelt a mozgás és amennyiben igen, akkor hogyan. 
A fej mozgatása az emberi testhez hasonlóan a nyak segítségével lesz megvalósítható. Ehhez elöször is sorra vettük, hogy a jelenlegi nyak milyen elemekböl áll, majd összeállítottuk azon elemek listáját, amelyekkel a későbbiekben ki kell egészíteni. Azt tudtuk, hogy mindenképpen szükség lesz egy forgástengelyre, a kérdés csak az volt, hogy e körül milyen mozgás átalakítással történjen a mozgatás. Több javaslat átgondolása után végül a fogaskerék kapcsolódásra szavaztunk.

Ahhoz, hogy a fogaskerekeket meg tudjuk határozni, szükségünk volt egy kiinduló nyomatékra, ahhoz pedig egy motorra.

Megvizsgáltuk a hajtás létrehozásának több lehetséges módját is, és végül a szervo-motor mellett döntöttünk. $+90^{\circ}$ és $-90^{\circ}$ közötti mozgatás megvalósítására az impulzusvezérlés a legalkalmasabb.

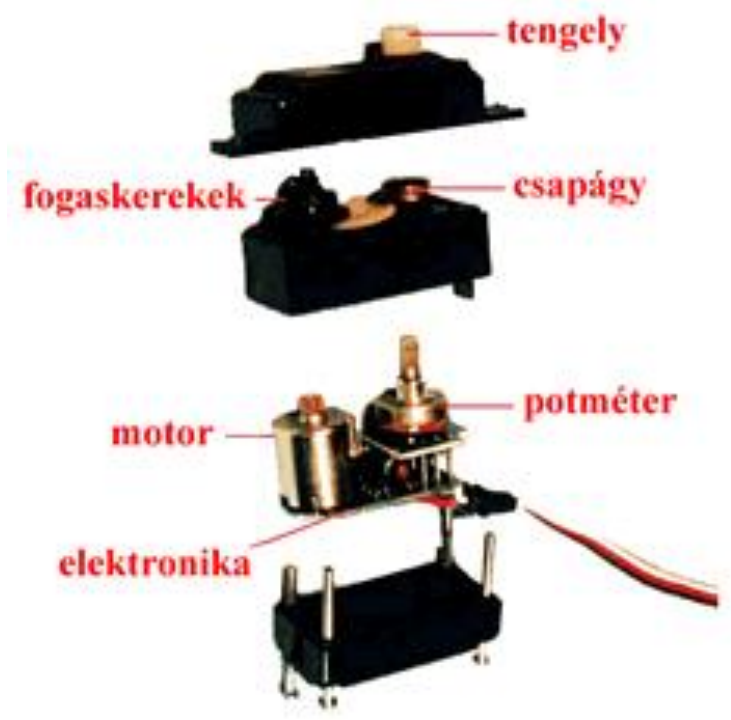

5. ábra. Szervomotor felépitése [2]

A motort egy ún. mikrokontroller, az ARDUINO UNO fogja vezérelni. Az ARDUINO-t egy olaszországi egyetemen fejlesztették, és C-alapú nyelven programozható. A programkódot egyszerüen, egy USB csatlakozón keresztül lehet a mikrokontrollerbe feltölteni. Tápegységként esetünkben a motor meghajtásához egy 9V-os elem is elegendö lesz. Ezen kívül szükségünk van még egy tranzisztorra és két kondenzátorra a szervomotor megfelelö müködtetéséhez.

Arra gondoltunk, hogy kiegészítjük a vezérlést még $3 \mathrm{db}$ mikrofonnal. A fejre két oldalt, illetve elöre szeretnénk egyet-egyet felszerelni. A mikrofonok feszültségjelet adnak le, és megfelelö programkód segítségével a szervomotor abba az irányba fogja fordítani a fejet, ahonnan a nagyobb feszültségjelet kapja.

Mivel Robi kiállításokra készül, ahol az alapzaj szintje is viszonylag magas, így szükségesnek tartottuk egy potenciométer beépítését is, amellyel szabályozni tudjuk a mikrofonok érzékenységét. A bekötést a 6 . ábra mutatja.

Ahhoz, hogy a vezérlést és a plusz elemeket be tudjuk építeni a fejbe, szükséges volt néhány átalakítást végeznünk, illetve meg kellett tervezni a fizikai megvalósulást is. Úgy gondoltuk, hogy a fej belsejébe tesszük be a vezérlés elemeit, mivel ott elegendő hely van, illetve, ha teszünk a fej hornyaiba plexi lapokat, akkor az egész elrejthető lesz.

Ezen kívül a motor kimenő tengelyére tervezünk egy fogaskereket, aminek a párja a 
forgástengelyen lesz. A müanyag fogaskerekek méretezéséről ugyan a [4] szakirodalomban találtunk elegendő információt, azonban mivel a motornak a mozgás létrehozásához egyedül a csapágyak gördülési ellenállását kell tudnia legyőzni, így elegendőnek tartottuk a geometriai méretezést elvégezni.

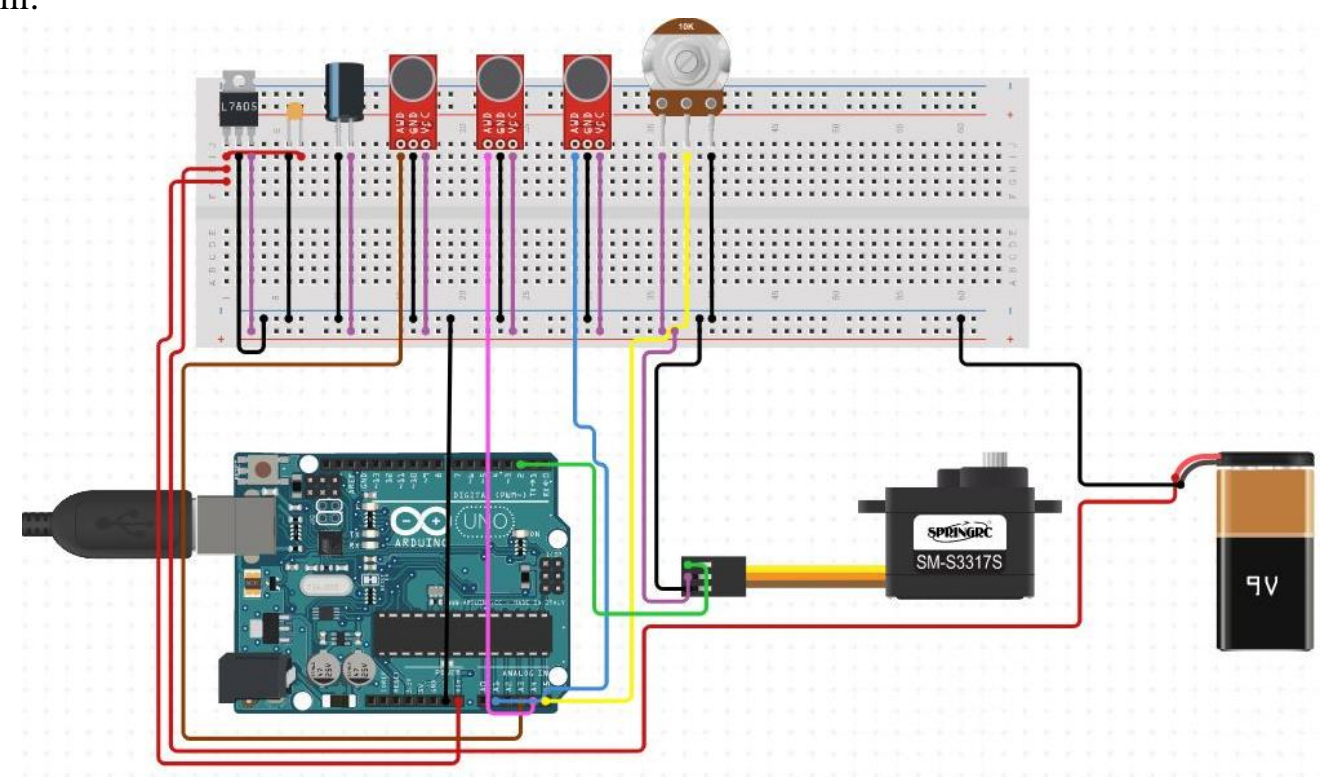

6. ábra. A vezérlés bekötése [3]

A fej összeépített rajzát az alábbi ábra mutatja.
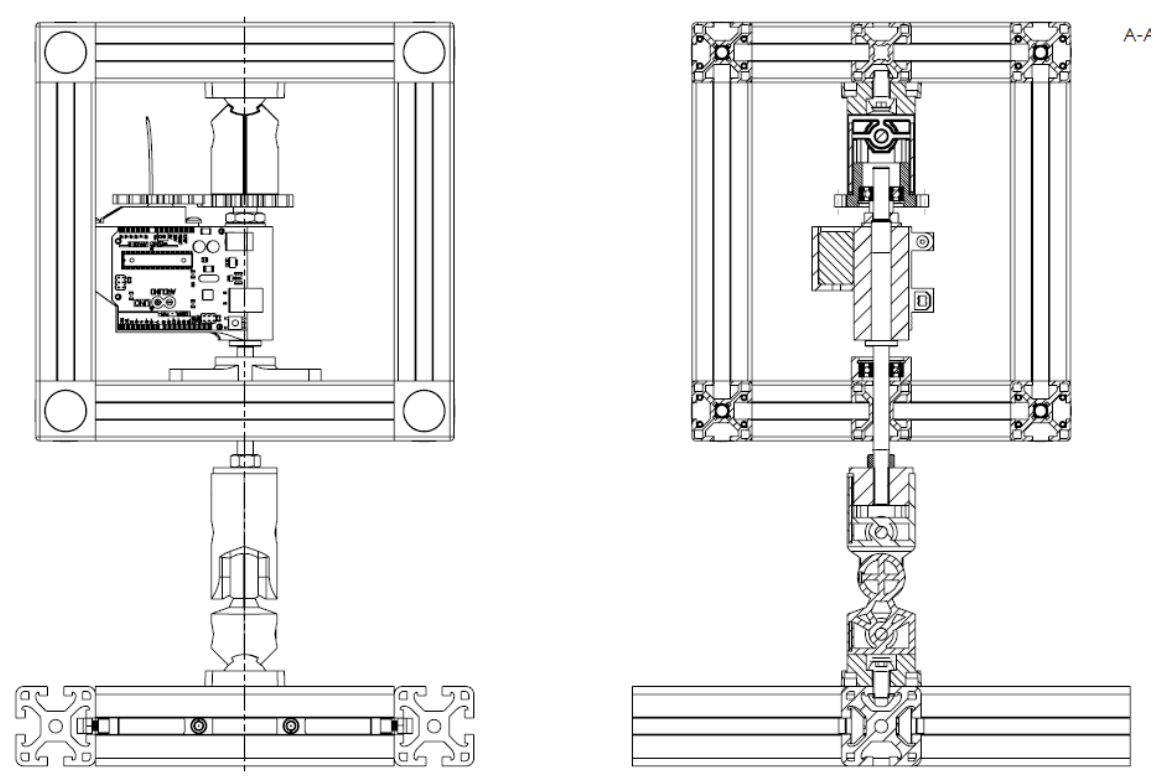

7. ábra. A szerkezet $2 D$ rajza 


\section{További feladatok}

Az így megtervezés alatt álló interaktív termékbemutató eszköz teljes dokumentációját egy MSc diplomatervként szeretnénk beadni, ahol terveink szerint bemutatható lenne a fej prototípus müködés közben. Ehhez még a továbbiakban fel kell szerelni rá a mikrofonokat és a müködtető szoftver végleges változatát el kell készíteni. Ha sikerül a mikrofonok érzékenységét is beállítani, és megszületik a végleges verzió, akkor forrasztott nyáklapon fogjuk az egyes részek csatlakozóit elhelyezni.

\section{Köszönetnyilvánítás}

A cikkben ismertetett kutató munka az EFOP-3.6.1-16-2016-00011 jelű „Fiatalodó és Megújuló Egyetem - Innovatív Tudásváros - a Miskolci Egyetem intelligens szakosodást szolgáló intézményi fejlesztése" projekt részeként - a Széchenyi 2020 keretében - az Európai Unió támogatásával, az Európai Szociális Alap társfinanszírozásával valósul meg.

\section{Irodalom}

[1] FATH Components Kft. katalógusa http://ec.fath24.media/ (letöltés dátuma: 2019.05.10)

[2] https://www.tankonyvtar.hu/en/tartalom/tamop412A/20110010_harsanyi_fizikai_szamitastechnika/ch14s03.html (letöltés dátuma: 2019.09.26.)

[3] https://www.circuito.io/ (letöltés dátuma: 2019.10.03.)

[4] Dr. Antal Miklós: Mủanyagok a gépészeti tervezésben II. kötet, Nehézipari Müszaki Egyetem, Gépelemek Tanszék, Miskolc, 1987. 482.-554. oldal 